production, and per capita traditional fuel consumption together explained $42 \%$ (all tropical countries), 33\% (Africa), 96\% (Asia) and $48 \%$ (Latin America) of variance in deforestation rate.

On the other hand, a forward stepwise regression analysis using independent variables that were significantly correlated $(P<0.05)$ with deforestation in tropical countries showed that population density $(\beta=0.57)$, external debt $(\beta=0.52)$ and cattle density $(\beta=0.32)$ are important in that order when all countries are considered together (Fig. 1). In Africa, population density has greatest effect on deforestation rate, in Asia crop-land area, and in Latin America cattle density. Again, the most significant results of our analyses are the differences between regions, also revealed by other analyse ${ }^{1,9}$.

Our analyses point to several possible causes of deforestation and have important policy and management implications. The availability of remote-sensing imagery and local data on socioeconomic variables, give us the potential to identify accurately the causes of deforestation at smaller scales; as we have done for the Sarapiqui region in Costa Rica (A. Sanchez-Azofeifa, S. D. and K. S. B., unpublished results) and the western Ghats, India (S. Menon \& K. S. B., unpublished results). Policies to stem deforestation must take into account regional as well as country-wide differences. More emphasis is needed on land distribution and agrarian reform in Latin America, where much of the land is used inefficiently for cattle ranching, and in Asia, alternatives must be found for subsistence-level agriculture, which drives agricultural frontiers onto marginal lands occupied by forests.

\section{Kamaljit S. Bawa}

\section{S. Dayanandan}

Department of Biology,

University of Massachusetts, Boston,

100 Morrissey Boulevard,

Boston, Massachusetts 02125, USA

e-mail:bawa@umbsky.cc.umb.edu

1. Forest Resource Assessment 1990, Survey of Tropical Forest Cover and Study of Change Processes. (FAO Forestry Pap. 130, Food and Agriculture Organization of the United Nations, Rome, 1996)

2. Myers, N. in The Causes of Tropical Deforestation (eds Brown, K. \& Pearce, D. W.) 27-40 (University College London Press, 1994)

3. Myers, N. Science 268, 823-824 (1995).

4. Brown, K. \& Pearce, D. W. (eds) The Causes of Tropical Deforestation (University College London Press, 1994).

5. Cropper, M. \& Griffiths, C. Am. Econom. Rev. 84, 250-254 (1994).

6. Capistrano, A. D. \& Kiker, K. B. Ecol. Econom. 14, 21-29 (1995). 7. Kahn, J. R. \& McDonald, J. A. Ecol. Econom. 12, 107-123 (1995).

8. Pearce, D. W. \& Brown, K. in The Causes of Tropical Deforestation (eds Brown, K. \& Pearce, D. W.) 2-26 (University College London Press, 1994).

9. Rudel, T. \& Roper, J. Ambio 25, 160-166 (1996).

10. Kummer, D. \& Sham, C. H. in The Causes of Tropical Deforestation (eds Brown, K. \& Pearce, D. W.) 146-158 (University College London Press, 1994)

11. World Resources 1994-1995 (World Resources Institute, Washington DC, in collaboration with the United Nations Environmental Programme and Development Programme, Oxford Univ. Press, Cambridge, 1994).

\section{Kinked DNA}

Kinks are thought to be important in DNA-protein interactions ${ }^{1}$ but evidence for their existence in free DNA has previously been indirect. The atomic force microscope (AFM) allows direct visualization of molecular structure in situ ${ }^{2,3}$, and using our newly developed AFM (magnetic a.c. mode or MacMode $)^{4}$ we have observed small DNA circles change from smoothly bent to abruptly kinked shapes. This effect was dependent on the presence of specific divalent cations. The DNA was bent smoothly in the presence of $\mathrm{Mg}^{2+}$, but consisted of nearly straight segments connected by kinks in the presence of $\mathrm{Zn}^{2+}$.

Tandem sequence repeats of $\mathrm{d}(\mathrm{A})_{5}$ and $\mathrm{d}$ (GGGCC $[\mathrm{C}]$ ) bend DNA ${ }^{5}$. We ligated the following oligomer:

CCCAAAAAGGGCCAAAAAGGGCCCAAAAAGGGCCAAAAAGGG

TTTTTCCCGGTTTTTCCCGGGTTTTTCCCGGTTTTTCCCGGG

to produce DNA circles. Maximum formation of circles occurs when the ligated oligomers are 126-base-pairs long. DNA longer than this forms superhelices, and thermal fluctuations are needed to bring the ends together. As a result, the larger closed circles are axially strained on ligation. We extracted circles and purified them as described elsewhere ${ }^{6}$. We placed DNA solutions $\left(0.5 \mathrm{mg} \mathrm{ml}{ }^{-1}\right.$ in $1 \mathrm{mM}$ $\mathrm{Mg}^{2+}$ or $\mathrm{Zn}^{2+}$ ) into the sample cell of a scanning probe microscope (PicoSPM; Molecular Imaging Corp., Phoenix, Arizona) where the molecules adsorbed spontaneously onto a mica substrate. Images were obtained in situ and remained stable on repeated scanning.

DNA images obtained in the MacMode had an average full-width at half-height of $3.5 \mathrm{~nm}$, so the instrumental broadening is little more than $1 \mathrm{~nm}$, a significant improvement in resolution over previous AFM technologies. DNA circles of 168 base pairs in $1 \mathrm{mM} \mathrm{MgCl}_{2}$ are smoothly curved, with less than one abrupt bend or kink per molecule (Fig. 1a).

When molecules from the same sample are imaged in $1 \mathrm{mM} \mathrm{ZnBr}$, their appearance changes dramatically (Fig. 1b). The DNA consists of nearly straight segments connected by abrupt kinks. This phenomenon was not observed in 126-base-pair circles, so we conclude that axial strain is required for this conformational change. The relative lack of kinks in the presence of $\mathrm{Mg}^{2+}$ and the absence of kinks in smaller circles under all ionic conditions demonstrate that single-strand breaks did not cause the kinks.

The strong enhancement of kinking observed here in the presence of $\mathrm{Zn}^{2+}$ is qualitatively consistent with earlier electron microscopy ${ }^{7}$ and electro-optical ${ }^{8}$ studies. If

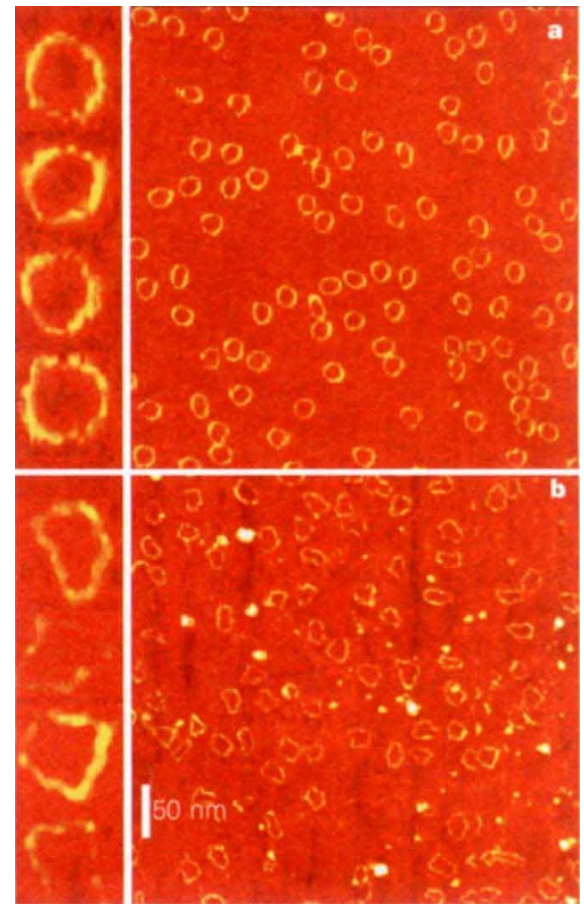

Figure 1 Images of 168-base-pair DNA minicircles in $1 \mathrm{mM} \mathrm{MgCl}_{2}$ (a) and $1 \mathrm{mM} \mathrm{ZnBr}_{2}$ (b), showing a fourfold increase in kink density in $\mathrm{Zn}^{2+}$. Selected molecules are displayed magnified by a factor of four to the left of each image. The tip was oscillated at $25 \mathrm{kHz}$ with an amplitude of $5 \mathrm{~nm}$ and the image was acquired in five minutes.

kinks are readily generated in vivo through a combination of axial strain and appropriate ionic conditions, then one might speculate that local writhing stress, to which DNA is subjected during various regulatory events, may promote the formation of localized kinks at specific DNA sequences. These could serve as signals for the assembly and/or localization of nucleoprotein complexes.

Wenhai Han

\section{S. M. Lindsay}

Department of Physics and Astronomy,

Arizona State University,

Tempe, Arizona 85287-1504, USA

e-mail: stuart.lindsay@asu.edu

Mensur Dlakic

\section{Rodney E. Harrington}

Department of Biochemistry,

University of Nevada Reno,

Reno, Nevada 89557-0014, USA

\footnotetext{
1. Werner, M. H., Gronenborn, A. M. \& Clore, G. M. Science 271, 778-784 (1996)

2. Hansma, H. G. \& Hoh, J. Annu. Rev. Biophys. Biomol. Struct. 23, $115-139$ (1994).

3. Bustamante, C. \& Rivetti, C. Annu. Rev. Biophys. Biomol. Struct. 25, 395-429 (1996).

4. Han, W., Lindsay, S. M. \& Jing, T. Appl. Phys. Lett. 69, 4111-4114 (1996)

5. Dlakic, M. \& Harrington, R. E. Proc. Natl Acad. Sci. USA 93, 3847-3852 (1996).

6. Dlakic, M. \& Harrington, R. E. J. Biol. Chem. 270, 29945-29952 (1995).

Laundon, C. H. \& Griffith, J. D. Biochemistry 26, 3759-3762 (1987).

8. Nickol, J. \& Rau, D. C. J. Mol. Biol. 228, 1115-1123 (1992).
} 